\title{
WOMEN EMPOWERMENT AT HOUSEHOLD AND RESOURCE DEVELOPMENT OF KALYANI COMMUNITY DEVELOPMENT BLOCK IN NADIA DISTRICT OF WEST BENGAL
}

\author{
Mr. Sudip Bhattacharya \\ Dr. Prasenjit Deb
}

\begin{abstract}
Empowerment is the re-distribution of power to challenge the ideology of male dominance. It is the greater transformation of the structure of institutions that prohibits reinforcing and perpetuating gender discrimination. Women empowerment is giving legitimate power and authority to perform the tasks and thereby bring forth a paradigm shift. This study is pivoted around women empowerment through decision making authority at household and community related matters. For this study, one specific community development block namely Kalyani of Nadia district of West Bengal has been chosen for intensive quality survey. Both quantitative and qualitative data have been used to obtain reliable result. Data were derived from a questionnaire survey of a sample of 100 respondents in one CD bloc viz. Kalyani. The correlation analysis, regression and step down method have been used to analyze the data to find out the relationship and significant differences using SPSS software package. Such a study would help us realize the meaning and reality of women empowerment which is an essential factor in the progress and development of the society.
\end{abstract}

Keywords: Women Empowerment, Decision making, Child marriage, Gender discrimination, Women education, Higher education, Child dropouts etc.

\section{Introduction}

It can be seen that women work much more than men in the family, but when they are introduced in the society, they are called the wife of such and such. For example, no matter how hard a farmer's wife works, her identity at the end of the day is that of a farmer's wife (William, 1977). It seems like no male will ever give up the right voluntarily. 
Women need to be aware of their own rights and power relations. For this we need expansion of education and social awareness. The state has taken various steps to increase and develop women's awareness. Engels says that women's emancipation is possible only when women have the opportunity to participate in every activity of society with equal importance ("The Origin of the Family, Private Property and the State, 1884" by Friedrich Engels). The Central Government and West Bengal government has taken several steps for the development of girls; these popular social schemes have not just helped the rural and urban population in Bengal, but have also attracted kudos from the international forum. Beti Bachao Beti Padhao campaign, Kanyashree to empower rural women. This scheme will help to bring financial empowerment to rural women.

\section{Related Review of Literature}

The gender ideology model, proposes that attitudes toward gender roles are responsible for the division of household labour (Coverman, 1985; Deutsch et.al., 1993; Kluwer et.al., 1997, 2000).

Though after an extensive research, Yadav (1985) concluded that rural women were keen to take up income generating activities, they still have a long way to go. It was found out that Dari-making, tailoring and knitting were the most preferred activities.

Aggarwal (1988) observed that "the involvement of women was found to be higher in animal husbandry and child care activities than in agricultural activities", indicating that there has been a slow but steady paradigm shift .

Kashyap (1988) found that "rural women had a working day of 16 hours 58 minutes in peak season and 16 hours 04 minutes in slack season, out of which 7 hours 7 minutes and 8 hours 44 minutes were spent on household activities in two seasons respectively".

\section{Objective of the Study}

a) To measure the scope of female work participation improvement during the study period.

b) Identify specific developmental initiatives which have an impact on women empowerment.

c) To verify the role of education and employment in influencing their status as decision makers at the family level.

\section{Data Sources}


Initially, I started with structured schedule for data collection of one hundred families in the Kalyani community development block. In fact, one of the tools I used the most was observation. The interview was the main method used for data collection. Data for my objectives were collected mainly from adult men and women.

\section{Result and Discussion}

Table - I: Correlation Analysis between dependent variable effectiveness of Kanyashree One Time Grant $(\mathrm{Y})$ and 17 casual variables.

\begin{tabular}{|l|c|}
\hline \multicolumn{1}{|c|}{ Variables } & ' $r$ ' Value \\
\hline Financial condition of the family $\left(X_{3}\right)$ & $.2903^{* *}$ \\
\hline Housing condition $\left(X_{4}\right)$ & $.3129^{* *}$ \\
\hline Association with Self Help Group $\left(X_{6}\right)$ & $-.2878^{* *}$ \\
\hline Availing bank loan $\left(X_{8}\right)$ & $-.2014^{*}$ \\
\hline Nature and extent of savings $\left(X_{10}\right)$ & $-.2145^{*}$ \\
\hline
\end{tabular}

Here, we have tried to understand how the Kanyashree one-time grant $(Y)$ by independent variable has affected the girls economically. I conducted this assessment on 100 families in a rural community block of Nadia district in West Bengal.

Despite financial difficulties, parents kept trying to continue education of their daughters. This one-time allowance of the Kanyashree project has helped these families considerably. The positive result has been shown as financial condition of the family $\left(\mathrm{X}_{3}\right)$.

From the above study, I noticed that no matter how hard life is for these families they care about its improvement. In spite of hundreds of hardships, they have paved the way to reduce the headaches. The positive result, Housing condition $\left(\mathrm{X}_{4}\right)$, above bears its witness.

Most families have been seen taking loans from Self Help Groups and private banks also. The negative results, Association with Self Help Group $\left(\mathrm{X}_{6}\right)$ and availing bank loan $\left(\mathrm{X}_{8}\right)$ are proofs of that.

Having received the money for this Kanyashree project, they were benefited by providing higher education to their daughters. Otherwise there would have been a lot of difficulties. Nature and extent of savings $\left(X_{10}\right)$, is the negative result that carries its message. 
Towards Excellence: An Indexed, Refereed \& Peer Reviewed Journal of Higher Education / Mr. Sudip Bhattacharya \& Dr. Prasenjit Deb / Page 82-87

Table - II: Correlation Analysis between dependent variable the perception level of students on women empowerment $(Z)$ and 23 casual variables

\begin{tabular}{|l|c|}
\hline \multicolumn{1}{|c|}{ Variables } & ' $r$ ' Value \\
\hline Changes are mainly in your village $\left(\mathrm{X}_{11}\right)$ & $.3572^{* *}$ \\
\hline Do not encourage the girl to do anything $\left(\mathrm{X}_{23}\right)$ & $-.2069^{*}$ \\
\hline
\end{tabular}

For Table - I \& Table - II Critical value (2-Tail, 0.05) = +or- $0.197 \quad{ }^{*}$ Significant at $5 \%$ level Critical value (2-Tail, 0.01$)=+$ or- $0.256 \quad * *$ Significant at $1 \%$ level

In the above observation, an idea of what is meant by women's empowerment ( $Z$ ) comes from the statements of the parents. Parents tried to make their daughters selfreliant.

In this study we the positive result is also reflected i.e. changes mainly in your village $\left(X_{11}\right)$. Therefore, the families of this region have paid special attention to the education of the girls as well as their home.

In this section, do not encourage the girl to do anything $\left(\mathrm{X}_{23}\right)$ represent negative result. Quite unfortunately, even today the rustic families cannot think that their daughters will work from outside the house or work from outside the house at night. Families encourage their daughters to work from home.

\section{Conclusion}

Apart from these many welfare schemes for women and children like Beti Bachao Beti Padhao Scheme, Kanyashree Project, Ruposhree Project, Ujjwala, ICDS, Kishori Skakti Yojana etc., have been launched by the State \& Indian governments. In view of the above, it may be expected that with a strong determination, commitment, and involvement of people and organisations with philanthropic motive and a rational outlook, the problem that women faced, can be solved and hurdles be overcome for promoting national rejuvenation and development. They should also be given the right to take their own decisions and also to make their own choices. It is very important to give them equal rights to participate in social, religious and public activities. Women should be given the equal social state in society by giving them equal rights for social and economic justice. Every woman should be given an equal opportunity for education and they should also get an equal employment opportunity without any gender bias. It is very important to provide them with a safe and comfortable working environment. The main advantage of women empowerment is that there will be an overall development of 
the society. The money that women earn does not help them and their family but it also helps the society to develop.

\section{Recommendation}

Beti Bachao Beti Padhao campaign, Kanyasree Project and other laws like RTE Act should be implemented to try to get girls to school. Limited educational opportunities for girls, especially in rural areas, also increase the risk of child marriage. A focus on Education, Employment, Violence against Women and the larger umbrella of a Comprehensive Social Protection Mechanism are critical to the emancipation of women across the country, and it is only through such emancipation that the nation will develop as a whole. 


\title{
References
}

1. https://censusindia.gov.in/2011 www.census2011.co.in/census/state/west+bengal)

2. www.wbkanyashree.gov.in

3. Weber, M. (1968) Basic Concepts in Sociology. New York: Citadel Press.

4. Chatterjee,A. (1975) A statistical profiles Landless agricultural women workers, Indian Farming 25(8):31-33.

5. Sharma,U.M. (1980) Women, Work and property in North-West India. London Publications, P.130.

6. Coverman, S. (1985) Explaining husbands" participation in domestic labor. Sociological Quarterly, 26, 81-97.

\author{
Mr. Sudip Bhattacharya \\ Research Scholar \\ Department of Lifelong Learning \& Extension \\ University of Kalyan \\ $\&$ \\ Dr. Prasenjit Deb \\ Head, \\ Department of Lifelong Learning \& Extension \\ University of Kalyan
}

